\title{
Reading to Learn: A literature review within a South African context
}

\author{
Tracey Millin \\ Department of General Linguistics, Stellenbosch University, South Africa \\ E-mail: millintracey@gmail.com
}

\begin{abstract}
Academic literacy development within the secondary schooling system in South Africa has reached crisis proportions, with a large number of students exiting the system unable to function adequately within the tertiary sector or labour market. Attempts to remedy this crisis by introducing curriculum reform over the past few years have yielded little success, with universities having to take on the literacy problem by offering a variety of remedial programmes to ensure that students are equipped to access learning and succeed at their studies. Research shows that most literacy intervention programs at universities appear to favour a more traditional approach to English academic language development by focusing on grammatical rules, sentence structure, spelling and punctuation. This bottom-up approach does not necessarily equip students with the skills needed to write coherent and cohesive extended pieces of writing as required by university assessment processes. For this reason, the Reading to Learn (RtL) methodology was chosen to be implemented within a writing module at the University of KwaZulu-Natal and within selected Grade 11 classes in the Winelands District in an attempt to find an alternative approach to academic literacy development. The purpose of this article is to offer a comprehensive synthesis of some of the theoretical assumptions of RtL as well as its practical implementation before embarking on an evaluative study of this methodology in future papers. In doing so, this article offers a brief discussion on academic literacy pedagogies and situates RtL within these frameworks. This is followed by a synthesis of the practical implementation of RtL and a discussion of the works of Halliday $(1989,1996)$, Vygotsky $(1978)$ and Bernstein $(1990,1996)$ which have had an influence on the development of RtL.
\end{abstract}

Keywords: academic literacy, Reading to Learn, academic reading and writing pedagogies, genre pedagogy, scaffolded learning

\section{Introduction}

The national language-in-education policy of South Africa mandates the use of English as the medium of instruction (MoI) for all students from Grade 4 onwards. Despite an ongoing debate about the benefits of mother tongue education on student success, and the unintended outcome of excessive mother tongue code-switching in classes where English is deemed a barrier to learning, 
this article takes the following as a point of departure: the reality that, for the majority of secondary school students, English is the default MoI even in classes where, for an overwhelming majority of students and educators, English is a second, third or even foreign language. To some extent, this offers an explanation for the poor English literacy development of a large majority of secondary school students in South Africa. A consequence of this reality is that unequal opportunities for learning are presented to these students which also results in unequal learning outcomes. In such cases, an inability to develop more advanced English academic literacy skills becomes an indicator for academic marginalisation, exclusion and alienation at secondary school level and later at tertiary level. Because Reading to Learn (RtL) was developed to bring marginalised students into the mainstream in the Australian education system (Rose and Martin 2012), and thus provide equal opportunities for learning for all students, there is good reason to test the efficacy of RtL in a South African secondary school and university context. I acknowledge that RtL is one of many available literacy interventions that could be utilised in South African classrooms or lecture halls to assist in academic literacy development. However, given that I was introduced to this intervention during my teacher training, I have became more interested in the intervention because it has a number of distinct features which may render it suitable for South African school-based interventions in a similar way to its appropriateness for Australian classrooms. These include a pedagogy designed to be appropriate for adolescent students, an inclusive pedagogy with regard to diversification of cultural and linguistic factors found within multilingual and multicultural classes, a close link to conventional national curriculum standards and practices, flexible modes of delivery, and a strong supportive base for advanced literacy development which applies to reading, writing and grammar skills. The aim of this article is to offer an overview of RtL and its practical implementation in classrooms by providing a summary of the literature as far as the conceptual framework of RtL is concerned. The article begins with a discussion of academic reading and writing pedagogies, and where RtL is situated with respect to various pedagogical paradigms. Secondly, an overview of the practical application of RtL is presented. Thirdly, the developing conceptual framework of RtL is discussed, which synthesises the seminal works of Halliday $(1989,1996)$, Vygotsky $(1978)$ and Bernstein $(1990,1996)$, all of whom have had a strong influence on the origination of RtL. Lastly, a concluding section is given.

\section{Literacy, academic reading and writing pedagogies, and Reading to Learn}

Literacy skills development of students in South African schools post-Apartheid might lead one to conclude that education is a high-cost, high-enrolment, yet low-quality system (Taylor 2009: 12). The future looks bleak, if the following statistics from the Department of Basic Education (2013) are anything to go by: $61 \%$ of Grade 6 and 9 English first-language students scored less than 50\% for the 2012 English Annual National Assessment (ANA) exam, while $75 \%$ of Grade 6 and $79 \%$ of Grade 9 English second-language students failed to score above 50\%. Furthermore, given the arguably high levels of social and distributional inequality in South African education today (UNESCO 2011: 87), students from lower socio-economic communities fail to break the cycle of poverty. Policy recommendations for increased student performance in South Africa are impressive but fail to focus on the practical component of teaching and learning. For example, improved school infrastructure, better school management, enhanced feeding schemes, increasing the number of qualified teachers, and improving teacher and school accountability are a few valuable proposals which may foster more equitable learning outcomes in South African schools. However, none of these offer a practical solution to the improvement of actual teaching and learning of literacy skills in the classroom. To ensure the most disadvantaged educational facilities (at primary, secondary and tertiary levels) have the capacity to provide quality literacy 
programmes, low-cost strategies need to be developed to assure that even "no-fee" schools can access them. Such an intervention has been developed, albeit for the Australian educational context, in the form of RtL.

Before unpacking the conceptual framework of RtL, the concept of 'literacy' needs to be defined, as it can be rather ambiguous given the evolution of concepts such as 'new literacies' and 'multimodal literacies', to name a few. For the purposes of this article, "literacy" refers to a student's ability to read English texts fluently and with comprehension, write English texts coherently, synthesise different information sources and offer a critical awareness of the information at a grade-appropriate level to ensure access to knowledge and success in education (UNESCO 2011). RtL is not confined to the English language only, but can be applied in any language, and encompasses the improvement of literacy skills ranging from pre-foundation phase to tertiary level. Some criticism may arise regarding my use of such a limited definition of literacy but, given the particular concern espoused by various stakeholders regarding the poor standard of reading and writing skills of South African students, it stands to reason that literacy is discussed from a reading and writing perspective only for the purposes of this article.

Literacy pedagogies often include one perspective of reading and writing. For example, traditional pedagogies foreground linguistic features of written texts and ensure that students are presented with the regularities and "rules" related to particular forms of written texts only (Luke and Freebody 1997). Socio-literate approaches emphasise that writing is a social practice and is shaped by social forces as much as it is shaped by linguistic and cognitive processes (John 1997, Jackson 2005). Furthermore, socio-literate pedagogies expose the multifaceted and often countless meanings and uses that reading and writing can have for different communities (Swales 1990, Gee 1996). Behaviourist pedagogies, which use basal readers and phonics programmes, focus on the development of literacy skills of individual students by communicating systematised information of language structures and curriculum content. Progressivist pedagogies, such as "whole language" literacy models, focus on the personal development of individuals through the acquisition of cultural and personal abilities (Martin, Christie and Rothery 1987). Critical pedagogies aim to change political relations between groups of individuals through the teaching of critical literacy skills (Freire 1970, Bourdieu 1991). Social-psychological models, which use genre-based methods, are also concerned with changing power associations. This is achieved largely through the transmission of literacy skills via institutionally privileged discourses (Rose and Martin 2005).

None of the abovementioned approaches are without fault, though. For example, socialpsychological approaches, which make use of genre-based methods ${ }^{1}$, erroneously assume that all students have access to formal educational discourse ${ }^{2}$. Personal experience has also highlighted that genre-based pedagogies may result in the development of "mechanical" writers who are less confident to deviate from genre model guidelines given in class, thereby failing to produce autonomous students who can apply and adapt the genre guidelines to different writing tasks (Millin

\footnotetext{
${ }^{1}$ Genre teaching comprises the explicit teaching of organisational patterns and structures found within differing types of "genres" developed to meet differing social purposes.

${ }^{2}$ Here, "discourse" refers to the use of language in a specific way to meet formal educational expectations. For example, this may refer to more formal academic language. Generally, the term (written with a lower-case 'd') refers to language in use. However, when the use of language is combined with other social practices - such as ways of doing, behaving, believing, dressing, and customs and practices - then the term "Discourse" (with a capital ' $\mathrm{D}$ ') is used.
} 
2011, 2015). Equally, critical (literacy) pedagogies are often inconsistent with regard to distinguishing between critical literacy and critical reading. For example, critical reading asks for an objective analysis of authorial intention, rendering the practice positivistic in nature. In contrast, critical literacy maintains that what constitutes knowledge is not neutral. Instead, it is based on the discursive rules of individual communities, and is therefore both ideological and interpretivist in nature (Cervetti, Pardales and Damico 2001). In South Africa, unless students are given the necessary skills to increase their level of criticality, they are merely likely to perform mechanical critical reading and may fail to achieve critical literacy objectives as set out by the new Curriculum Assessment Policy Statement (CAPS). It needs to be made clear that often the confusion between critical literacy as pedagogy and critical reading as a way of engaging with content is not a shortcoming, but is most likely a problem that scholars have in making a clear distinction between similarly termed but differently aligned educational matters. From the explanation above, it becomes increasingly clear that literacy development in the classroom should not be perceived simply as the adoption of one pedagogic approach or the "mastery of a fairly discrete set of decoding and encoding skills" (Jackson 2005). Rather, literacy development programmes need to integrate aspects of numerous approaches. RtL's approach to literacy development attempts to synthesise the various pedagogies mentioned above, as illustrated in Figure 1 below. Instead of adopting one particular viewpoint of academic literacy pedagogies, RtL has managed to incorporate multiple aspects of the progressivist, behaviourist, social-psychological, critical and constructivist pedagogies, resulting in an intervention that is supposedly able to fast-track development of literacy skills within any phase of the curriculum and across all subject specialisations (Rose 2006, Acevedo 2010).

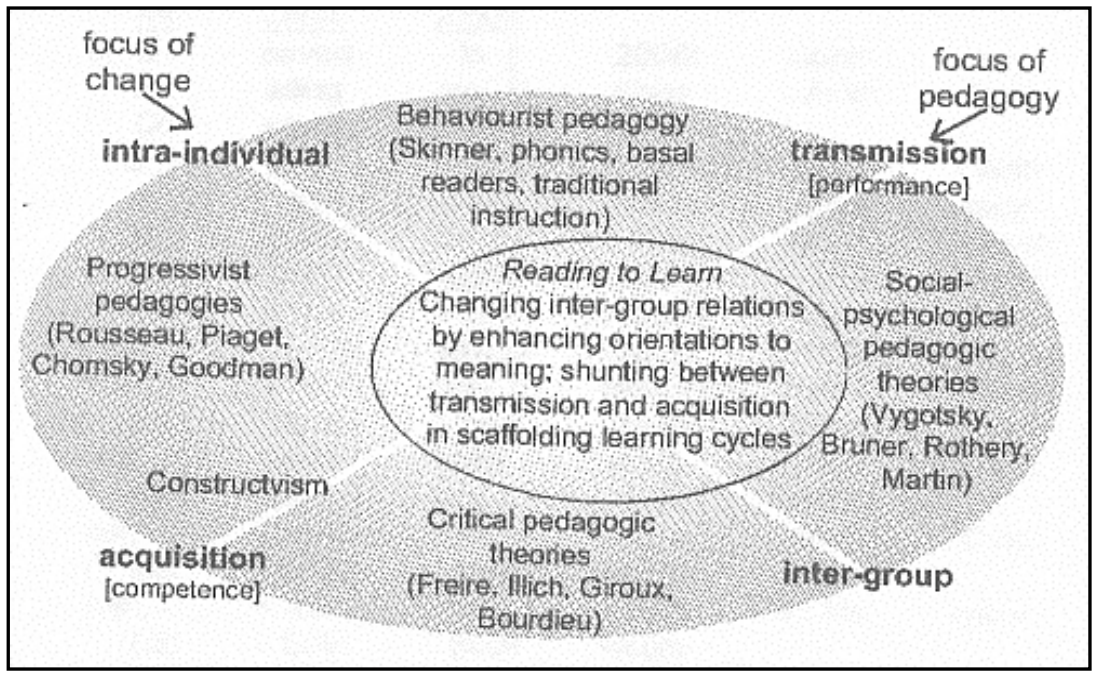

Figure 1: Types of pedagogy that collectively comprise Reading to Learn ${ }^{3}$

\section{Reading to Learn}

RtL is a teaching and learning methodology for literacy development. It includes a professional teacher development programme that was developed in Australia over a number of years to meet the needs of a community of students who typically find it difficult to gain access to learning content due to serious lags in their literacy development (Rose 2004, Rose and Martin 2012). The

\footnotetext{
${ }^{3}$ Taken from Rose (2007).
} 
programme is based on three core principles. The first principle derives from the assumption that reading provides the primary mode of learning. Thus, the explicit teaching of reading concurrently with the teaching of curriculum content is advised. Teachers then need to integrate the teaching of reading and writing skills across all subject disciplines (Rose and Acevedo 2006). This means that all teachers, regardless of subject discipline, are considered literacy teachers. Secondly, unlike current trends in education in South Africa which see class activities pre-determined by student ability, all students in the same classroom are taught at the same level of reading and writing skills to ensure that the abilities gap commonly found in classrooms and maintained by differentiated learning is not maintained or exacerbated. Thirdly, learning supposedly takes place when teachers are able to offer students support beyond their current abilities, thereby ensuring that students reach higher levels of learning through purposeful scaffolding ${ }^{4}$ (Rose and Acevedo 2006). Thus, RtL is able to facilitate learning across the curriculum, and improve the chances of academic success of traditionally marginalised students whilst simultaneously adding value to the learning and progress of those students already deemed to be strong students. RtL is founded on an understanding of grammar developed in Systemic Functional Linguistics. This means that a particular perspective on language is foregrounded where language is supposedly determined socially rather than mentally.

One of the main achievements of RtL is its ability to minimise educational inequality. This is accomplished by using a pedagogy that is focused on supporting students in their acquisition of crucial orientations to reading and writing, achieved by careful scaffolding in a purposefully designed teaching cycle (Rose 2006). For example, if one examines university academic requirements, the primary skill that students require for access and success is the ability to learn autonomously from reading (Rose, Rose, Farrington and Page 2008), as university courses generally require large portions of academic texts to be read before lectures. Thus, the function of the lecture is to synthesise and build upon information offered in the course readings (Rose et al. 2008). Students are then required to demonstrate their understanding by way of written assignments. However, according to Rose et al. (2008), the traditional academic cycle (see Figure 2) assumes that students come to university already equipped with the skills necessary for autonomous learning from reading, a skill that should have been developed in the secondary school phase. Consequently, students already disadvantaged by a poorer quality of secondary school education (and who are incapable of autonomous learning from reading), are further disadvantaged at a tertiary education level ${ }^{5}$. From Figure 2, the assumption that the secondary school system has adequately prepared students to cope with the traditional academic cycle cannot be taken for granted. It is no surprise then that university academics in South Africa are faced with, for example, relatively high rates of attrition as far as lecture attendance is concerned. Failure to read and understand what has been read before lectures, coupled with student attrition, means that tutorial sessions fail to remedy an already systemic problem in relation to weaker performing students. This implies a failure of such students to demonstrate adequately in writing what has been learnt, which in turn translates into a breakdown in the traditional academic cycle.

\footnotetext{
4 "Scaffolding" refers to the input teachers give to students to assist them in producing tasks that they ordinarily would not be able to complete on their own.

${ }^{5}$ There are numerous reasons why students fail to comprehend what they read, especially as far as English secondlanguage or additional-language speakers are concerned. Some reasons might be: students have not adequately developed their home language vocabulary, which then limits the extent of mental representations required to comprehend what has been read in the English text; students do not read at a fast enough pace to achieve a minimum reading fluency required to comprehend what has been read; or students lack the motivation to read, especially academic texts, which undermines the traditional academic cycle.
} 


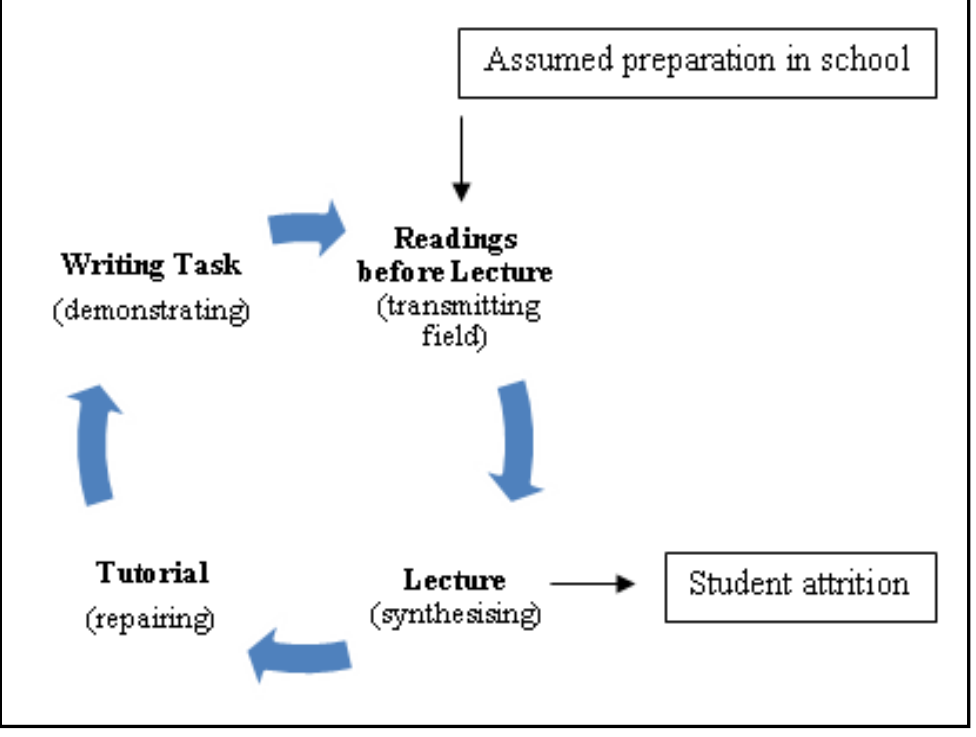

Figure 2: The traditional academic cycle ${ }^{6}$

In an effort to overcome barriers to learning imposed by the traditional academic cycle, the first phase of the RtL cycle, "Preparing for Readings" (see Figure 3), is used to address the inequitable suppositions of the traditional academic cycle. Instead of insisting that students spend their time outside of lectures or classes independently reading abstract course texts, which can be demotivating for second or additional language students, some class time is used to assist students in reading difficult texts with critical comprehension (Rose et al. 2008). Similarly, some class time is also used to guide students through the writing process (see Figure 3 ). Aspects concerning the processes of reading and writing may not necessarily be taught by the subject lecturer or class teacher, but rather a language specialist in conjunction with the lecturers or teachers concerned. For example, the University of KwaZulu-Natal's (UKZN) Department of Economics has a dedicated language specialist who offers reading and writing lectures to extended degree students. The texts to be used in the literacy development classroom are "authentic" (of subject-specific relevance) and are best chosen in conjunction with subject lecturers to ensure that the benefit to students is maximised. Similarly, the academic literacy support offered to selected Grade 11 students during a pilot study ${ }^{7}$ of RtL within a secondary school context made use of curriculum-based work, thereby ensuring that the teaching of academic reading and writing was carried out alongside the teaching of curriculum content. (See the Appendices for an example of materials developed for an academic argument essay with one set of Grade 11 students.)

\footnotetext{
${ }^{6}$ Taken from Rose et al. (2008).

${ }^{7}$ This formed part of my PhD study on the efficacy of RtL with selected Grade 11 students in the Winelands District (Millin 2015).
} 


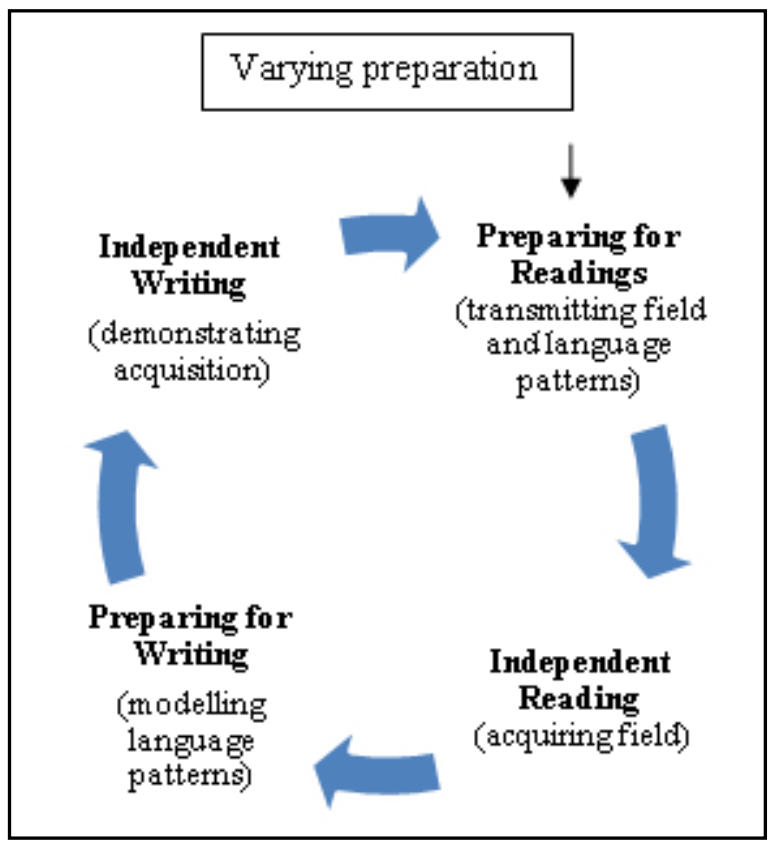

Figure 3: The scaffolded academic cycle ${ }^{8}$

The four-stage scaffolded academic cycle (Figure 3) can be expanded upon, resulting in a sixstage RtL cycle (not included for discussion here due to word limitations) which can be implemented in both secondary school classrooms and tertiary-based academic writing modules (as well as primary schooling) to raise students' academic literacy skills. Upon first glance, any person familiar with school-based teaching practices and tertiary teaching in South Africa might argue that the RtL cycle is likely to be too onerous and time-consuming to implement effectively given the stringent CAPS requirements and university curriculum constraints. However, one must bear in mind that the RtL cycle is meant to be used for dedicated reading and writing lessons, which usually comprise only one or two lessons, at the most, out of a scheduled five or six lessons per week or per cycle at school. A more detailed explanation of the RtL cycle within the secondary schooling context can be found in Millin (2015), which seeks to elucidate how such a process can be practically implemented in South African classrooms to ensure better preparation for tertiary studies.

\section{The conceptual framework of Reading to Learn}

\subsection{Halliday - Language as a text within a social context}

Reading texts in English is an immensely challenging task for non-native speakers of English, and even more so for students who have not yet developed Cognitive Academic Language Proficiency (CALP) in either their home language or mother tongue (L1), or first additional language (L2), regardless of whether a student's L1 or L2 is used as the MoI at school (Millin 2015). This is because the ability to grapple with the complexities of reading and writing involves the ability to recognise and replicate patterns of language on three different levels, namely the levels of "discourse semantics", "lexicogrammar" and "graphology" (Halliday 1996), as illustrated in Figure 4. The most noteworthy difference between Halliday's approach to reading

\footnotetext{
${ }^{8}$ Taken from Rose et al. (2008).
} 
and writing, and the approach adopted in schools in South Africa currently is that the former adopts a top-down approach whereas the latter, for the most part, adopts a bottom-up approach. If having acquired CALP is a necessary condition to access the complexities of academic texts encountered at a tertiary level, one should not be surprised to find that scores of students navigate their way into tertiary education in South Africa only to find that they are ill-prepared to cope, let alone succeed, with the rigors of academic discourse ${ }^{9}$.
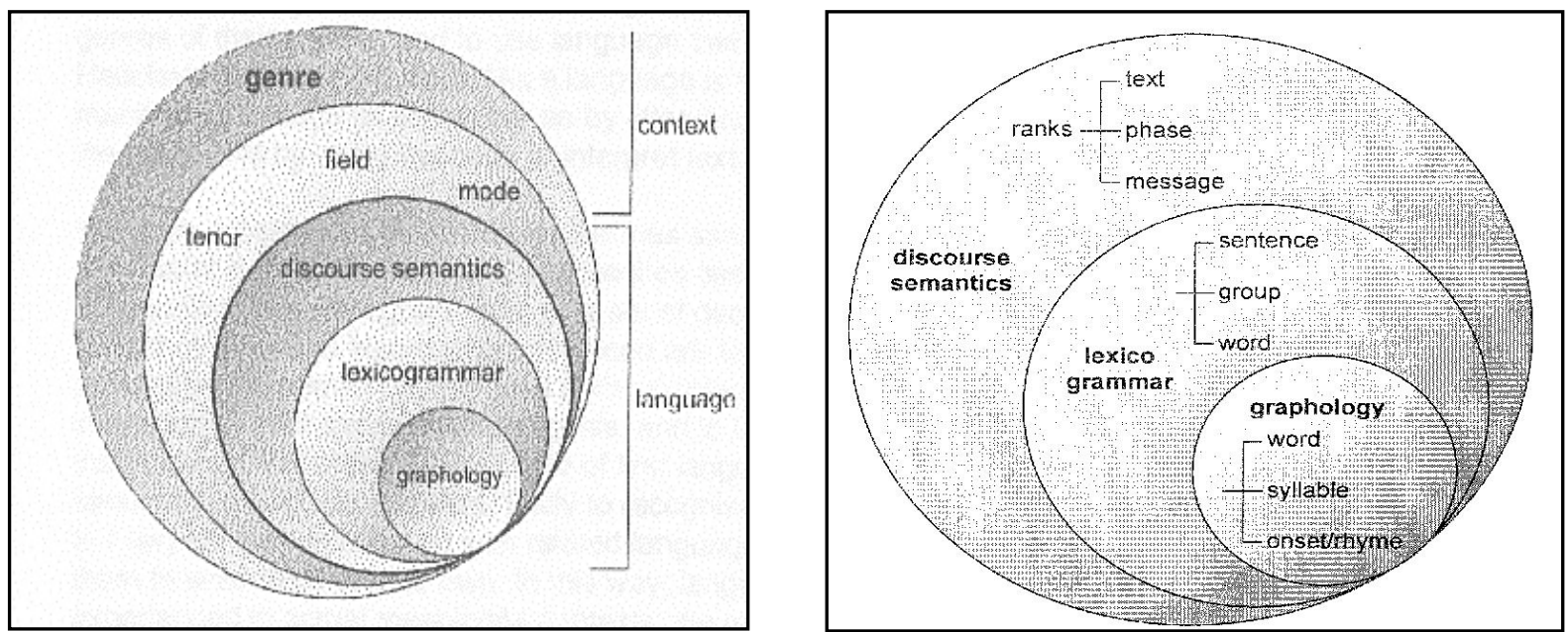

Figure 4: Halliday's (1996) stratified model of language ${ }^{10}$

The following explanations of Halliday's (1996) "discourse semantics", "lexicogrammar" and "graphology" are synthesised from Rose and Acevedo (2006) and Rose and Martin (2012).

"Discourse semantics" relates to aspects of language beyond the clausal level. Readers need to be able to recognise what the text is about and how it is organised. For example, students need to be able to recognise the sequence of events in narratives or chunks of information in factual texts. This entails a recognition and interpretation of the genre of the text which would then allow students to ascribe the text to a specific purpose and organisation. See Appendix A for an example of a schematic map of an academic argument used with selected Grade 11 students in a South African pilot run of RtL (Millin 2015).

"Lexicogrammar" relates to aspects of language at the phrasal and clausal level. Readers need to be able to recognise the arrangement of words within phrases while simultaneously recognising the function of each phrasal component. For instance, students need to be able to recognise the subcomponents of clauses that provide information about processes (what is being done - verb phrases), participants (who or what the sentence is about - noun phrases) and circumstances (where, when, why and how).

"Graphology" relates to aspects of language at the word level. Readers need to be able to recognise what each word means within the text and how individual letters are arranged to form particular words. Put differently, students need to be able to understand how individual symbols come together to form individual words.

9 Other studies which have also reported on the under-preparedness of undergraduate students are Troskie-De Bruin (1999), Penrose (2002), Van Schalkwyk (2008) and Allardice (2013).

${ }^{10}$ Both figures appear in Rose and Acevedo (2006), and Rose and Martin (2012). 
Because of the complexities of accessing texts, as illustrated above, it is argued that the teaching of literacy needs to be "simplified" (complex patterns need to be broken down) to assist students in accessing all three levels of a language (Rose 2005), whilst simultaneously ensuring students' affective filters are not raised due to the stressful nature of reading tasks (Krashen 1981). Very briefly, the affective filter is an impediment to language acquisition - or learning of any kind, for that matter - caused by undesirable emotional responses to learning environments. Therefore, anxiety and stress can inhibit language learning as these emotional factors function as filters between the input being provided and the amount of input the student is able to take in (Krashen 1981). By breaking down a text, for example, the task becomes less stressful, and students are able to make sense of the text in question. An understanding of the text at a global (or genre) level offers the foundation for students' understanding of the overall text. The genre of a text offers insight into the field, tenor and mode ${ }^{11}$ (Millin 2015). Similarly, individual sentences can only make sense in relation to other sentences that come before and/or after it, and these links need to be made clear to students (Rose 2006, Hart 2009). Equally, words within a text only make sense in relation to the other words used in close proximity. Therefore, the conceptual framework which informs RtL, from Halliday's (1996) point of view, assumes that if students understand what the text is about (discourse semantics) and how clauses within the text are arranged (lexicogrammar) to provide crucial information, students will be better equipped to recognise the meaning of individual words (graphology).

According to Rose (2006), the ability to understand these complexities provides students with access to written codes of knowledge, and the ability to unlock the usefulness of "devices" used to convey meaning. Given that students in secondary schooling and tertiary education in South Africa are required to read "specialised" academic texts to access curriculum content, and subsequently write about the material, an ability to access the three levels of texts becomes crucial. Arguably, most teachers are of the opinion that the availability of subject-specific technical terms, together with their definitions, is sufficient for English Second Language (ESL) students to access meaning within abstract, technical texts (Cohen, Glasman, RosenbaumCohen, Ferrara and Fine 1979). However, other research has shown that a mastery of technical terms and vocabulary is not the solution to accessing academic content (Selinker, Todd Trimble and Trimble 1976). Furthermore, access to non-technical aspects of texts, such as specialised referencing devices (for example, lexical and grammatical cohesive devices as well as theme and rheme patterning), created greater barriers in accessing meaning. Therefore, according to Rose (2006), problems related to the accessibility of meaning are often closely related to a lack of information and attentiveness to the function of rhetorical devices used within texts. Given the complexity of academic texts, students especially at tertiary level need intensive scaffolding in how meaning is conveyed in these texts, and not only assistance in accessing technical terms found within academic texts ${ }^{12}$. However, if this scaffolding can be provided earlier, at secondary school level, students might find the transition to university easier with regard to accessing abstract academic texts. This leads to a discussion of the second theoretical perspective, advanced by Vygotsky (1978), which underpins the conceptual framework of RtL.

\footnotetext{
11 "Field" refers to what is going on in the text or what the text is about. "Tenor" refers to the participants involved in the text as well as the relationship between participants, their roles and status or rank, and the permanency of the relationships. "Mode" refers to the type of channel used for communication.

${ }^{12}$ An inability to understand simple conjunctives was evident in my teaching experience at UKZN. Students did not understand how certain conjunctives indicated that opposing viewpoints of a thesis were being presented. Consequently, when asked to paraphrase all the positive attributes of living in rural contexts, students gave both the positive and negative attributes. This is because conjunctives such as "however", "on the contrary" and "in contrast" were simply misunderstood.
} 


\subsection{Vygotsky - Learning as a social process}

Current pedagogic practices in South African schools are closely aligned with the incremental learning model, formalised through Piaget's (cited in Wadsworth 1984) theory of innate developmental stages. In other words, teachers provide a diagnostic form of assessment, and then present activities or tasks to students based on their assessed abilities (Rose 2005). According to Rose (2005), progressivists view this practice as "student-centred". However, the problem in South Africa remains that the "ability" gap between weaker and stronger students is rarely closed, as teaching and learning tasks are controlled by the competence of students. RtL aims to close this gap by incorporating aspects of Vygotsky's (1978) theory of social learning into its pedagogic practice. RtL incorporates three fundamental aspects of Vygotsky's theory of learning as a social process, namely social interaction, mediated learning, and the zone of proximal development (ZPD). Very briefly, the ZPD is the gap between an individual student's actual academic literacy capability and his or her potential capability, which results from collaboration with a significant (more capable) other, such as a peer, mentor or teacher.

At school and university, students are usually required to demonstrate what they have learnt through written assignments. Complex patterns of language are needed to assist students in the successful completion of these tasks. However, if a student is left to develop this sophisticated grasp of language on his or her own, most students from working class, oral-cultured families would most likely fail at doing so (a more detailed discussion of this is beyond the scope of this article and incorporates a discussion of assimilation into formal educational Discourse). Therefore, RtL makes use of social interaction in supportive environments to assist students in developing more advanced levels of understanding of academic texts, more advanced than they would otherwise have been if these levels of understanding were to develop individually (Vygotsky 1978). Vygotsky (1978) refers to this metaphorical "place" as the ZPD. It is within this zone that marginalised students are given the "skills" to complete tasks (for example, understand academic texts and other related material) independently. Because students develop the ability to imitate patterns of thought or spoken language through intensive scaffolding from a significant other, they increasingly develop the ability to comprehend academic texts and produce their own without the assistance of others (Mitchell and Myles 2004). They therefore develop academic autonomy. The amount of assistance is gradually reduced until students are able to integrate the new skills into their own consciousness. The support offered by educators gradually shifts to become internal and self-governing, and is indicative of a successful process of scaffolding.

According to Vygotsky (1978, cited in Schaffer 2004), students ordinarily develop advanced forms of reasoning and awareness through collaboration with others more accomplished than themselves. It is through these social interactions that students acquire the critical cultural skills needed to participate in society. These skills include communicative skills that students need in order to be able to access pedagogic strategies, such as RtL, which are used for the development of literacy skills. Furthermore, these skills are considered the same as Bernstein's $(1990,1996)$ "restricted and elaborated codes of consciousness". As far as the application of RtL in the Australian context is concerned, because most Aboriginal students come from oral-cultured families, skills related to elaborated codes of consciousness are not necessarily passed on to these students before they start school. It could be argued that the reality of most South African students, in terms of a childhood orientation to an oral culture, is not too dissimilar to the experience of non-native English speakers in Australia. Therefore, it becomes critical to employ 
literacy intervention strategies that address this obstacle. As such, RtL was designed with this barrier in mind.

Learning as a social process, and the resultant acquisition of cultural skills (for example, orientations to reading) needed to access academic texts, should take place through social interaction (Schaffer 2004). The type of language used in classrooms - for example, a higherorder versus lower-order language vocabulary - should be seen not only as a vital source of input for communication, but also as a crucial part of cognitive development. In other words, language becomes the "vehicle for thought" or channel of mediation in the development of CALP (Mitchell and Myles 2004). Consequently, it is language that guides students' thoughts and directs their attention to important rhetorical devices within academic texts, highlighting the link between understanding of academic texts and communication. Thinking is facilitated by communication and the type of language used (amongst others), which means that the learning of literacy skills becomes a "mediated process" (Schaffer 2004). However, development is necessary of the associations between students' own frames of reference and abstract concepts presented within academic texts. For students who have already had access to some rhetorical devices, a process of assimilation takes place. However, for students who have limited academic proficiency in their native or home language - a plausible assumption for many South African students - a process of accommodation needs to take place, which can often be problematic and time-consuming when one considers that students in any particular classroom context have different language abilities. Nevertheless, Mitchell and Myles (2004) argue that it is during this mediated process of language usage that students are supported in the development and control of their unique "mental tools". It is both through the supported development and subsequent use of these "mental tools" that students are able to access the three layers of text in Halliday's (1996) stratified model of language - see Figure 4 (Mitchell and Myles 2004).

The success of the mediated process is dependent upon shared processes and face-to-face interaction. Through interpersonal communicative strategies, students "pool" their understanding of the intricacies of academic texts, and cooperatively negotiate meaning and understanding of these texts. This collaborative understanding would not necessarily be possible if students attempted to do so independently. Conversations with highly-trained participants (educators) are vital for this process, as the thoughts and insights of these participants are internalised by students, resulting in greater control of mental processes. Similarly, communicative interactions with peers of better language ability, as well as educators, are important as both the level of interaction together with the interactants with better linguistic ability are considered the origin of new language, and consequently, new thought (Vygotsky 1978). Within the RtL cycle (Lemke 1990, Rose 2006), students are provided with the language and feedback necessary to comprehend academic texts. Within this cycle, the progression from interpersonal (or shared) speech to intrapersonal (or inner) speech allows for CALP to develop. However, one must bear in mind that this is not a random process, but takes place through explicit scaffolding within the student's ZPD. It must be noted that mediated learning through educator scaffolding may be a problematic process in the South African context. This is because few teachers in some rural schools possess the necessary qualifications or native English-speaking proficiencies needed to generate "new", higher-order language and thinking patterns necessary to advance academic literacy. It would seem tautologous to say that improving educator skills in English language proficiency is an important part of strengthening the process of mediated learning; nonetheless, efforts by the Department of Basic Education in building language capacity would be a catalyst to ensuring the 
success of literacy interventions, such as RtL, which rely strongly on significant others to build language capacity.

\subsection{Bernstein - Education as a pedagogic device}

Section 2 of this article highlighted the dismal literacy performance of students at secondary school level, with students studying English as a first additional language (L2) more likely to face the full brunt of the growing literacy problem (UNESCO 2011). Research has shown that there tends to be a difference in literacy performance of students from well-resourced, former model $\mathrm{C}^{13}$ schools as opposed to students coming from township and rural schools (UNESCO 2011, Millin 2015). Given this scenario, it becomes too easy to assign the literacy outcome of students solely to socio-economic circumstances. However, one should possibly be attributing lower levels of performance to issues such as poorer levels of early childhood linguistic stimulation and possibly a lack of early socialisation into the dominant Discourse of formal education (Duncan and Seymour 2000, Ghosh 2013). Both Bernstein (1996) and Rose and Martin (2012) articulate that, all too often, the academic performance of students is attributed to innate biological abilities and cultural associations. This is not to be disputed, however, this does not necessarily account for the poor academic performance of some students, where an association between academic performance and innate biological abilities becomes the scapegoat for legitimising individual failure instead of looking at unequal opportunities for quality learning at some schools (Bernstein 1996).

Rose and Martin (2012) attempt to make a case for the fact that literacy development curricula at schools fail to provide explicit instruction in reading and writing after the first two years of schooling. This is often linked to competence models of education (Rose 2005). In competence models of schooling, the literacy development curriculum presupposes an already established, innate educational competency due to the fact that, apparently, all students arrive at school with the necessary pre-orientations to the dominant discourse of formal education (Rose 2005). Consequently, literacy instruction after the first two years of schooling becomes implicit, with the teacher's role being that of the "guide on the side". Bernstein (1996), Rose (2005), and Rose and Martin (2012) further argue that knowledge systems necessary for successful assimilation into the school Discourse (see fn. 2 for an explanation of this term) are construed to be invisible to the student struggling to assimilate into the Discourse of the school. Given this scenario, teachers within a competence model of schooling assume that all learners entering the formal educational domain are already successfully assimilated into the Discourse of schooling, and thus fail to explicitly help students make the transition (Rose 2005). In practical terms, this could relate to reading and writing skills. Less assistance with regard to reading and writing is given beyond the second year of primary school, so if a student still has not mastered (either of) these skills by then, he or she may struggle to become an independent reader and/or may have difficulty writing later on. According to Bernstein (1996), this is not because of an innate biological fault on the student's part; rather, it is more likely due to unequal opportunities to access formal learning.

In direct contrast to the competence model of literacy development, RtL supposedly adopts more of a performance model. With this model of literacy development, classroom attention is given to the learning of specialised literacy skills needed to complete specific academic tasks

\footnotetext{
${ }^{13}$ Former White schools during Apartheid.
} 
at school (Rose 1999). The skills needed to become successful learners in a discourse possibly foreign to some students are made explicit during classroom interaction. In this scenario, the teacher moves from being the "guide on the side" to being the "sage on the stage" (Bernstein 1996). With interventions like RtL and the attempt to make knowledge specific to formal educational Discourse more visible to students, the age-old metaphor of the "hidden curriculum", applicable to many educational systems, might possibly be rectified (Rose 2005). To understand the concept of the 'hidden curriculum' in education, one needs to look simultaneously at the role of instructional and regulative classroom discourse (Rose 2005). According to Rose (2004), reading often forms the basis of most school-based activities. As a result, educators need to place a strong emphasis on helping students develop systematic approaches to reading skills development. Reading is crucial in that students cannot write about knowledge that they have not acquired through reading-based activities (Hart 2009). It is thus plausible to state that reading becomes a crucial pedagogic medium for accessing vital information, which means that well-developed reading skills become crucial for academic success (Bernstein 1990, Rose 2004). Given the importance of solid reading skills, this is a skill that needs to be developed well as early as possible within the literacy development curriculum. However, this becomes problematic within the South African school curriculum because unequal opportunities exist in which these crucial skills may fully develop. For example, according to UNESCO (2011), 75\% of primary school learners fail to meet minimum literacy benchmarks, with $45 \%$ of Grade 5 learners struggling to develop basic reading skills. Consequently, the negative impact that the role of instructional and regulative classroom discourse has on students' literacy development is reason to believe that this very discourse might be a strong component of student literacy insufficiencies (Rose 2004).

Instructional discourse refers to the multiple opportunities created in a classroom for the development of specialised reading and writing skills. Regulative discourse is the creation of an identity, and order and management of performance (Bernstein 1996, Rose 2005). In educational contexts, instructional discourse is embedded within a regulative discourse. In other words, instructional discourse involves skills development whereas regulative discourse involves the maintenance of social order (Rose 2005). According to Bernstein (1996), a lack of explicit instruction (regulative discourse) in academic literacy skills development (instructional discourse) is more likely to blame for unequal literacy development in students and not necessarily as a result of a student's innate biological ability. In discussing the above concepts, one also needs to bring into the discussion Bernstein's (1990) concept of 'codes of consciousness' or knowledge.

Middle-class discourse has the propensity of being categorised as elaborate, whereas workingclass discourse tends to be categorised as restricted (Rose 1999). According to Bernstein (1996), this is a possible reason for why children from working-class homes are more prone to underperformance in comparison to students from middle-class homes. A possible reason for this is the restrictions to various speech codes that working-class children encounter prior to starting school. Therefore, teachers should be offering suitable classroom practices that could help working-class students produce and respond better to meaning through apt codes of speech. In a schooling context, this may take the form of elaborated codes of consciousness. Having access to either restricted or elaborated codes of consciousness or knowledge affords students different ways of understanding meaning through experience (Bernstein 1996).

Halliday (1989) offers a different term for Bernstein's (1996) codes of language, namely “written or spoken forms of language". Just like elaborated and restricted codes of consciousness or 
knowledge, written (elaborate) and spoken (restricted) codes of consciousness necessitate different degrees of skill. Written codes are considered more cognitively demanding than spoken codes, partly due to the fact that speaking consists of face-to-face relations. With written codes, meaning is supported by non-verbal cues. Furthermore, written codes of knowledge are abstract because meaning is rooted in specific language patterns (for example, rhetorical devices such as lexical and grammatical cohesive devices). It is written codes of language patterns that RtL attempts to make more explicit to students who have not been given ample opportunities to immerse themselves into these discourses. The level of inequality regarding access to written codes of language is demonstrated by pre-school access to written or spoken forms of language (i.e. early childhood linguistic stimulation). Rose (2004) found that children from high-literate, middle-class families spent approximately 1000 hours engaging with reading material through or with their parents before starting their school careers. Consequently, these students are more likely to develop the necessary skills to engage efficiently with written texts. As a result, these students will more likely be able to learn to read within the early years of schooling. On the contrary, students coming from low-literate homes tend to have less access to written stories. As a result, these students are more likely to find it difficult to engage with written texts. Consequently, developing the skills necessary to become fluent readers early on at school might be an issue. These difficulties are compounded during each year of schooling as the curriculum increasingly demands more from these students, with the result that students like these tend to fall behind. This highlights probable faults embedded within the sequencing and pacing of the South African literacy development curriculum (Rose 2004), as illustrated in Figures 5a and 5b.

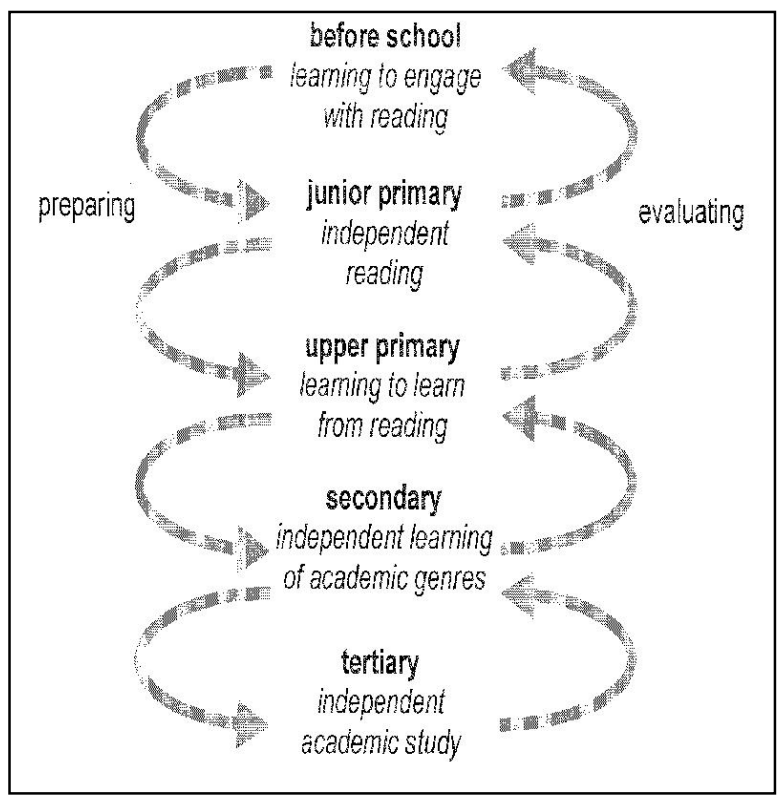

Figure 5a: The literacy development curriculum's impact on marginalised students - South African curriculum goals (Rose 2004)

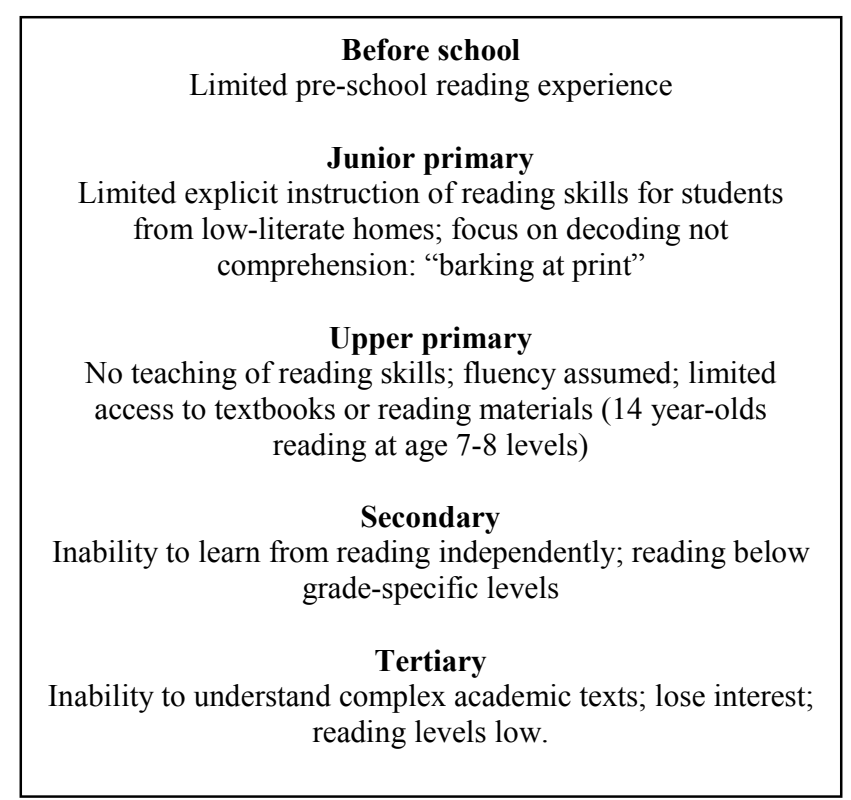

Figure 5b: The literacy development curriculum's impact on marginalised students - South African curriculum outcomes (Hart 2009)

According to Rose and Martin (2012), the disparity in academic achievement between workingclass and middle-class students is because the preparation of "successful" students in obtaining essential reading and writing skills is realised covertly during the secondary phase of schooling. 
At this stage of schooling, it is assumed that students are already capable of autonomous learning from reading. As a result of this assumption, a large proportion of curriculum-based content is set out as homework. This offers important learning opportunities necessary for the development of independent reading skills. Students able to read and write independently will probably be able to acquire content knowledge (Rose 1999). However, students unable to make (adequate) use of these learning opportunities may be excluded from the literacy development cycle. This is because the cycle is hierarchical in nature, as knowledge builds upon previously acquired knowledge and skill sets. Consequently, an inability to perform according to predetermined literacy curriculum goals and objectives (Figure 5a) at specific phases of schooling worsens students' chances of reaching appropriate reading and writing goals at a later stage. For this reason, it is possible to maintain that the end result of the pacing of the literacy development curriculum is twofold: students from high-literate homes are given more opportunities to succeed, whilst students from low-literate homes might be excluded from acquiring the skills necessary to succeed at school (Figure 5b). RtL was supposedly designed to remedy this scenario by providing explicit instruction in the teaching of academic reading and writing skills, and thus democratise the classroom by giving all students an equal chance of succeeding.

\section{Conclusion}

Given that academic literacy skills of secondary school students and university students have called into question the quality of teaching and learning of late, it becomes even more important to find alternative approaches to the teaching of reading and writing at both school and university levels. It must be noted that one particular approach to the teaching of academic literacy may not necessarily be appropriate in bridging the skills deficiency of students exiting the secondary school system. For this reason, given that RtL attempts to amalgamate a number of different academic reading and writing pedagogies, this methodology was chosen for evaluation purposes (the evaluative aspect will be reported on in a forthcoming article) in an attempt to bridge the skills divide of students entering the university system. This article focused on the practical implementation of RtL by offering an overview of how this methodology moves away from the traditional academic cycle towards a scaffolded academic cycle, the latter which is rooted in the theoretical assumptions of Halliday $(1989,1996$; language as a text in a social context), Vygotsky (1978; learning as a social process) and Bernstein (1990, 1996; education as a pedagogic device). A detailed discussion was presented of the seminal works of Halliday $(1989,1996)$, Vygotsky (1978) and Bernstein $(1990,1996)$, as an understanding of the conceptual framework of RtL is important if one is to engage in a critical evaluative study of the efficacy of RtL within a South African context. From the discussions presented above, it is clear that RtL could be considered theoretically sound. Given that a pilot study of RtL was conducted at the University of KwaZuluNatal in 2010, and has already been reported on (see Millin and Millin 2014), a strong recommendation is to pilot a similar study within select secondary school contexts to test the efficacy of RtL within a South African secondary school context. Although the context of schooling in South Africa is different to that of Australia, a recommendation for a RtL study within a South African context would be to utilise some sort of comparative method that tests whether RtL is truly an academic literacy intervention for a global audience. Furthermore, given the unique context of schooling in South Africa (teacher qualifications, overcrowded classrooms, low-literate students and dysfunctional schools in some geographic areas), it would be important 
to run a pilot study of RtL to test whether the intervention can assist students in the way that it was designed to, regardless of school contextual constraints.

\section{References}

Acevedo, C. 2010. Will the implementation of Reading to Learn in Stockholm schools accelerate literacy learning for disadvantaged students and close the achievement gap? Sweden: Multilingual Research Institute.

Allardice, S. 2013. Student Preparedness for Academic Writing. Unpublished Masters dissertation, Stellenbosch University.

Bernstein, B. 1990. The structuring of pedagogic discourse. London: Routledge.

Bernstein, B. 1996. Pedagogy, symbolic control and identity: Theory, research, critique. London: Taylor and Francis.

Bourdieu, P. 1991. Language and symbolic power. Cambridge: Polity Press.

Cervetti, G., M. Pardales and S. Damico. 2004. A tale of differences comparing the traditional, perspectives, and educational goals of critical reading and critical literacy. Available online: http://www.readingonline.org/articles/art index.asp?HREF=/articles/cervetti/index.html

(Accessed 15 July 2013).

Cohen, A., H. Glasman, P.R. Rosenbaum-Cohen, J. Ferrara and J. Fine. 1979. Reading English for specialized purposes: Discourse analysis and the use of student informants. TESOL Quarterly 13(4): 551-564.

Department of Basic Education. 2013. Annual national assessment: 2013 diagnostic report and 2014 framework for improvement. Pretoria: Department of Basic Education.

Duncan, L. and M. Seymour. 2000. Socioeconomic differences in foundation-level literacy. British Journal of Psychology 9(1): 145-166.

Freire, P. 1970. Pedagogy of the oppressed. New York: Continuum.

Gee, J. 1996. Social linguistics and literacies: Ideology in discourses. London: Taylor and Francis.

Ghosh, D. 2013. Socioeconomic status links to children's literacy development. Washington University Undergraduate Research Digest 9(1): 10-15.

Halliday, M. 1989. Spoken and written language. Oxford: Oxford University Press.

Halliday, M. 1996. On grammar and grammatics. In R. Hasan, C. Cloran and D. Butt (Eds.) Functional descriptions: Theory in practice. Amsterdam: Benjamins. pp. 1-38.

Hart, M. 2009. The Reading to Learn Programme: A Preliminary Motivation for its Implementation in South African Schools. Unpublished report. Pietermaritzburg. 
Jackson, F. 2005. Divine interventions: Needs analysis for post-graduate academic literacy and curriculum development in a South African school of theology. Language and Education 19(1): $50-73$.

John, A. 1997. Text, role and context: Developing academic literacies. Cambridge: Cambridge University Press.

Krashen, S. 1981. Second language acquisition and second language learning. California: Pergamon Press.

Lemke, J. 1990. Talking science: Language, learning and values. Norwood: Ablex Publishing Company.

Luke, A. and P. Freebody. 1997. Shaping the social practices of reading. In S. Muspratt, A. Luke and P. Freebody (Eds.) Constructing critical literacies: Teaching and learning textual practice. Cresskill: Hampton Press. pp. 185-225.

Martin, J. and D. Rose. 2005. Designing literacy pedagogy: Scaffolding democracy in the classroom. In J. Webster, C. Matthiessen and R. Hasan (Eds.) Continuing discourse on language. London: Continuum. pp. 251-280.

Martin, J.R., F. Christie and J. Rothery. 1987. Social processes in education: A reply to Sawyer and Watson (and others). In I. Reid (Ed.) The place of genre in learning: Current debates. (Typereader Publications No. 1). Geelong: Centre for Studies in Literary Education. pp. 46-57.

Millin, T. 2011. Scaffolding Academic Literacy with Undergraduate Social Science Students at the University of KwaZulu-Natal Using the Learning to Read: Reading to Learn Intervention Strategy: An Evaluative Study. Unpublished Masters dissertation, Edinburgh University.

Millin, T. 2015. Scaffolding Academic Literacy Using the Reading to Learn Methodology: An Evaluative Study. Unpublished PhD thesis, Stellenbosch University.

Millin, T. and M. Millin. 2014. Scaffolding academic literacy using the Reading to Learn intervention: An evaluative study of a tertiary education context in South Africa. Per Linguam 30(3): 26-38.

Mitchell, R. and F. Myles. 2004. Second language learning theories. London: Hodder Education.

Penrose, A. 2002. Academic literacy perception and performance: Comparing first-generation and continuing-generation college students. Research in the Teaching of English 36(4): 437-461.

Rose, D. 1999. Culture, competence and schooling: Approaches to literacy teaching in indigenous education. In F. Christie (Ed.) Pedagogy and the shaping of consciousness: Linguistics and social processes. London: Cassell. pp. 1-33.

Rose, D. 2004. Sequencing and pacing of the hidden curriculum: How indigenous children are left out of the chain. In J. Muller, A. Morais and B. Davies (Eds.) Reading Bernstein, researching Bernstein. London: Routledge. pp. 91-107. 
Rose, D. 2005. Democratising the classroom: A literacy pedagogy for the new generation. Journal of Education 37: 131-167.

Rose, D. 2006. Literacy and equality in the classroom. Future directions in literacy. Available online: www.edsw.usyd.edu.au/schools teachers/prof dev/index.shtml (Accessed 20 February 2013).

Rose, D. 2007. A reading based model of schooling. Pesquisas em Discurso Pedagógico. 4(2): $1-22$.

Rose, D. and C. Acevedo. 2006. Closing the gap and accelerating learning in the middle years of schooling. Australian Journal of Language and Literacy 14(2): 32-45.

Rose, D. and J. Martin. 2012. Learning to write, reading to learn: Genre, knowledge and pedagogy of the Sydney school. London: Equinox Publishing.

Rose, D., M. Rose, S. Farrington and S. Page. 2008. Scaffolding academic literacy with indigenous health sciences students: An evaluative study. Journal of English for Academic Purposes 7(3): 165-179.

Schaffer, R. 2004. Introducing child psychology. Oxford: Blackwell.

Selinker, L., R.M. Todd Trimble and L. Trimble. 1976. Presuppositional rhetorical information in ESL discourse. TESOL Quarterly 10(3): 281-290.

Swales, J. 1990. Genre analysis: English in academic and research settings. Cambridge: Cambridge University Press.

Taylor, N. 2009. The state of South African schools Part 1: Time and the regulation of consciousness. Journal of Education 46: 1-24.

Troskie-De Bruin, C. 1999. Academic Development: Bridging at a South African University. Unpublished Doctoral dissertation, Stellenbosch University.

UNESCO. 2011. The hidden crisis: Armed conflict and education. Paris: UNESCO Publishing.

Van Schalkwyk, S. 2008. Acquiring Academic Literacy: A Case of First-Year Extended Degree Programme Students at Stellenbosch University. Unpublished Doctoral dissertation, Stellenbosch University.

Vygotsky, L. 1978. Mind in society. Cambridge: Harvard University Press.

Wadsworth, B. 1984. Piaget's theory of cognitive development: An introduction for students' of psychology and education. New York: Longman. 


\section{Appendices}

\section{Appendix A: Basic Academic Essay / Exposition Genre (based on Rose (2007))}

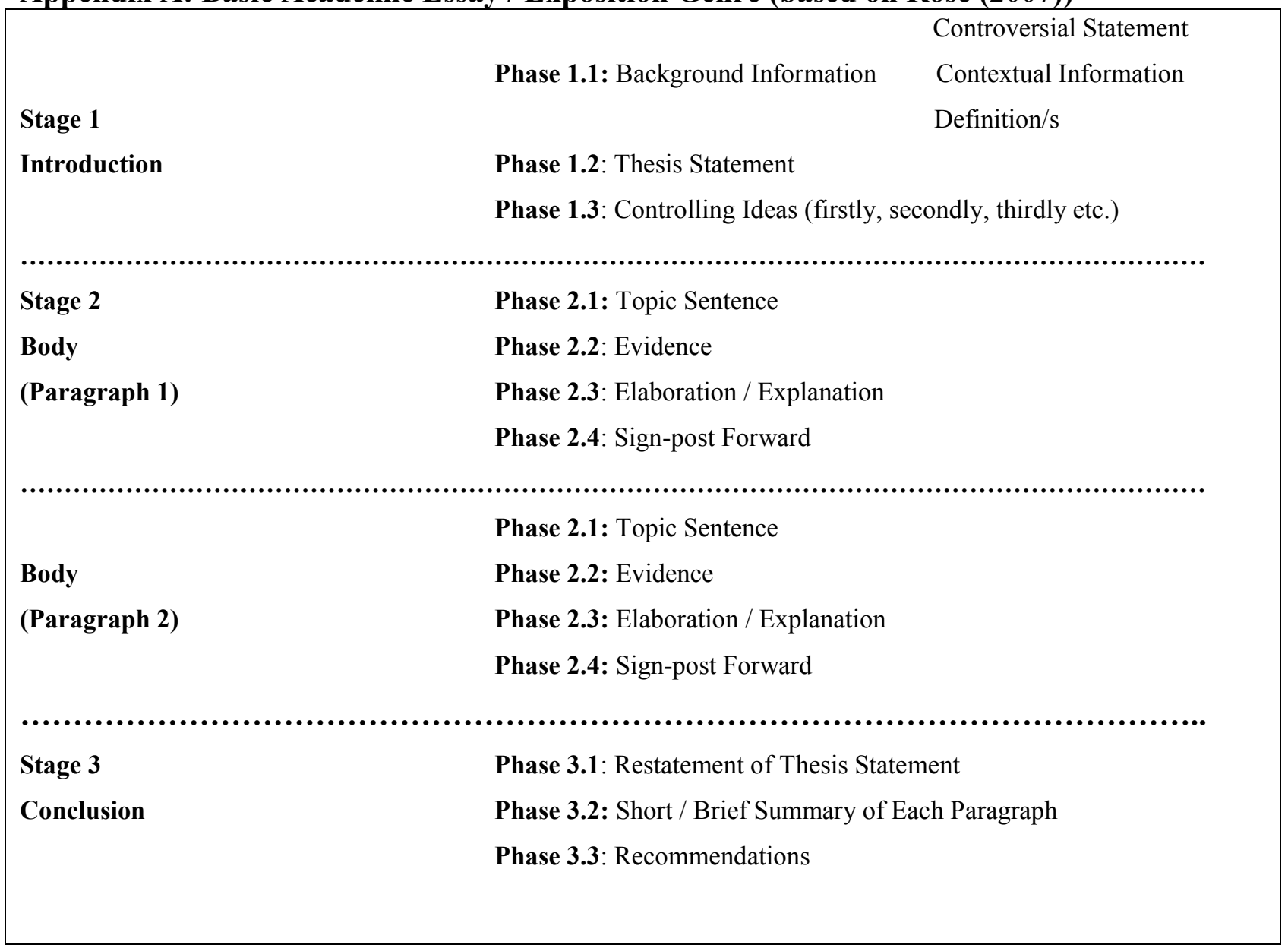




\section{Appendix B: Essay Question}

\section{In no more than one page (500 words), argue whether the novel "Buckingham Palace" by Richard Rive is relevant to the Grade 11 curriculum according to its historical context.}

Buckingham Palace is deemed a literary masterpiece of its time as it keeps alive the history of one of the most notorious yet dynamic communities of South Africa during the Apartheid era. The setting of the novel is District Six, an inner-city dwelling in Cape Town, home to largely the Coloured population of Cape Town. The novel is divided into three clear time segments, namely morning, afternoon and evening, with the mood of the novel taking on a darker tone as the time periods progress. As you jump through time, as the sunset gradually falls on this district, its characters and their homes are erased from the physical realm of Cape Town due to the infamous Group Areas Act of 1966. Despite tragedy and adversity, the community maintains its kinship. The Group Areas Act of 1966 was a move by the Apartheid government to declare District Six a Whites-only area, forcing nearly 60000 people from their homes to the desolate Cape Flats. It is for this historical perspective alone that "Buckingham Palace" is considered an important and relevant novel for the Grade 11 curriculum. Therefore, this essay will argue that "Buckingham Palace" is relevant and should remain as part of the Grade 11 curriculum. In doing so, this essay will draw links between historical events of the Group Areas Act of 1966 and events in the novel.

The Group Areas Act of 1966 left hundreds of District Six families homeless due to forced removals by the Apartheid government. The reason for these removals, according to the government of the time, was that District Six was a slum and provided the perfect grounds for crimes such as gambling, drinking and prostitution. For example, Zoot is the leader of the gang known as The Boys (pg 19) who is responsible for various petty theft crimes, and Mary, with "the girls", runs the Casbah brothel (pg 25). Despite the people of District Six feeling happy within their community, the government still declared it a "no-go" area and started with forced removals. This event is highlighted in Richard Rive's novel with the bulldozing of many houses in District Six (pg 36) and the forced removal of thousands of people to the desolate Cape Flats (pg 45). In writing about the events of District Six and the emotional turmoil that the characters experience, Richard Rive wants to keep alive the memory, whether good or bad, of the real historical events leading up to the forced removals which are not too dissimilar to countless forced removals which still happen in South Africa today, regardless of the racial group affected. This is a stark reminder that history does repeat itself and hence the importance of being reminded of past events. Therefore, by reading a novel such as "Buckingham Palace", one not only learns about the past, but may be taught how to avoid a similar act of cruelty in the future.

In conclusion, this essay argued that the novel "Buckingham Palace" is considered relevant and should remain part of the Grade 11 curriculum. This is largely due to the historical relevance of the novel as it portrays the events of the infamous Group Areas Act of 1966 which saw scores of District Six residents forced from their homes and moved to the Cape Flats. Richard Rive wanted to ensure, through the reading of this novel that the bad aspects of Apartheid were kept alive, thereby ensuring that past mistakes are not repeated. 